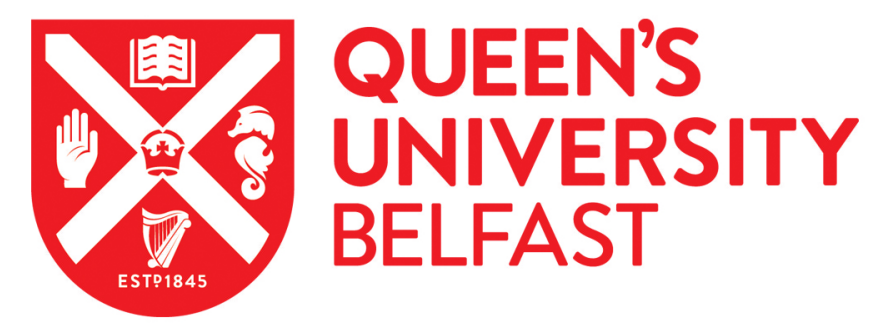

\title{
Purification, characterization and molecular cloning of chymotrypsin inhibitor peptides from the venom of Burmese Daboia russelii siamensis
}

Guo, C-T., McClean, S., Shaw, C., Bjourson, A. J., Rao, P-F., \& Ye, M-Y. (2013). Purification, characterization and molecular cloning of chymotrypsin inhibitor peptides from the venom of Burmese Daboia russelii siamensis. Peptides, 43, 126-132. https://doi.org/10.1016/j.peptides.2013.02.009

Published in:

Peptides

Document Version:

Peer reviewed version

Queen's University Belfast - Research Portal:

Link to publication record in Queen's University Belfast Research Portal

\begin{abstract}
Publisher rights
This is the author's version of a work that was accepted for publication in Peptides. Changes resulting from the publishing process, such as peer review, editing, corrections, structural formatting, and other quality control mechanisms may not be reflected in this document. Changes may have been made to this work since it was submitted for publication. A definitive version was subsequently published in Peptides, [VOL 43, (2013)]
\end{abstract}

\section{General rights}

Copyright for the publications made accessible via the Queen's University Belfast Research Portal is retained by the author(s) and / or other copyright owners and it is a condition of accessing these publications that users recognise and abide by the legal requirements associated with these rights.

Take down policy

The Research Portal is Queen's institutional repository that provides access to Queen's research output. Every effort has been made to ensure that content in the Research Portal does not infringe any person's rights, or applicable UK laws. If you discover content in the Research Portal that you believe breaches copyright or violates any law, please contact openaccess@qub.ac.uk. 


\section{Accepted Manuscript}

Title: Purification, characterization and molecular cloning of chymotrypsin inhibitor peptides from the venom of Burmese Daboia russelli siamensis

Authors: Chun-teng Guo, Stephen McClean, Chris Shaw, Ping-fan Rao, Ming-yu Ye, Anthony J. Bjourson

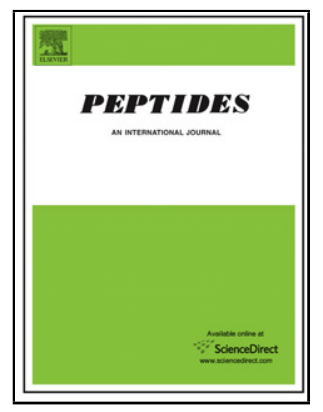

PII:

DOI:

Reference:

S0196-9781(13)00048-X http://dx.doi.org/doi:10.1016/j.peptides.2013.02.009

To appear in: $\quad$ Peptides

Received date: 29-1-2013

Revised date: 11-2-2013

Accepted date: $\quad 11-2-2013$

Please cite this article as: Guo C-t, McClean S, Shaw C, Rao P-f, Ye M-y, Bjourson AJ, Purification, characterization and molecular cloning of chymotrypsin inhibitor peptides from the venom of Burmese Daboia russelli siamensis, Peptides (2013), http://dx.doi.org/10.1016/j.peptides.2013.02.009

This is a PDF file of an unedited manuscript that has been accepted for publication. As a service to our customers we are providing this early version of the manuscript. The manuscript will undergo copyediting, typesetting, and review of the resulting proof before it is published in its final form. Please note that during the production process errors may be discovered which could affect the content, and all legal disclaimers that apply to the journal pertain. 


\section{Purification, characterization and molecular cloning of chymotrypsin inhibitor peptides from the venom of Burmese}

\section{Daboia russelli siamensis}

Chun-teng Guo ${ }^{\mathrm{a}, \mathrm{b}}$, Stephen McClean ${ }^{\mathrm{a}}$, Chris Shaw ${ }^{\mathrm{c}}$, Ping-fan Rao ${ }^{\mathrm{b}}$, Ming-yu Ye ${ }^{\mathrm{b}}$, Anthony J. Bjourson ${ }^{\mathrm{a}}$

${ }^{a}$ School of Biomedical Sciences, University of Ulster, Cromore Road, Coleraine BT52 1SA, Northern Ireland, UK

b The Institute of Biotechnology, Fuzhou University, Fuzhou 350002, Fujian Province, People's Republic of China

${ }^{c}$ School of Pharmacy, Queen's University, Belfast BT9 7BL, Northern Ireland, UK

Key words: Daboia russelli siamensis venom, chymotrypsin inhibitor, purification, characterization, cloning

*Corresponding author: Tel: +44-2870124406. Fax: +44-2870-124965.

Email:s.mcclean@ulster.ac.uk 


\begin{abstract}
One novel Kunitz BPTI-like peptide designated as BBPTI-1, with chymotrypsin inhibitory activity was identified from the venom of Burmese Daboia russelli siamensis. It was purified by three steps of chromatography including gel filtration, cation exchange and reversed phase. A partial N-terminal sequence of BBPTI-1, HDRPKFCYLPADPGECLAHMRSF was obtained by automated Edman degradation and a $\mathrm{Ki}$ value of $4.77 \mathrm{nM}$ determined. Cloning of BBPTI-1 including the open reading frame and 3' untranslated region was achieved from cDNA libraries derived from lyophilized venom using a 3' RACE strategy. In addition a cDNA sequence, designated as BBPTI-5, was also obtained. Alignment of cDNA sequences showed that BBPTI-5 exhibited an identical sequence to BBPTI-1 cDNA except for an eight nucleotide deletion in the open reading frame. Gene variations that represented deletions in the BBPTI-5 cDNA resulted in a novel protease inhibitor analog. Amino acid sequence alignment revealed that deduced peptides derived from cloning of their respective precursor cDNAs from libraries showed high similarity and homology with other Kunitz BPTI proteinase inhibitors. BBPTI-1 and BBPTI-5 consist of 60 and 66 amino acid residues respectively, including 6 conserved cysteine residues. As these peptides have been reported to have influence on the processes of coagulation, fibrinolysis and inflammation, their potential application in biomedical contexts warrants further investigation.
\end{abstract}




\section{Introduction}

Protease inhibitors are part of the composition of Russell's viper venom, in which they exhibit varying concentrations depending on their geographical distribution [21]. Trypsin and chymotrypsin inhibitors from snake venoms are members of the functionally diverse BPTI-like (bovine pancreatic trypsin inhibitor) superfamily. The snake venom Kunitz/BPTI inhibitors are basic polypeptides with approximately 60 amino acids in which there are six cysteine residues forming three conserved disulfide bridges. They exhibit diverse functions for inhibiting serine proteinase enzymes. This superfamily is classified into two families based on protein structure; small Kunitz-type inhibitors and BPTI-like toxins and soft tick anticoagulant proteins [5]. The Kunitz BPTI proteinase inhibitor family is divisible into subgroups according to source and bioactivity. Snake Kunitz/BPTI inhibitors have been divided into non-neurotoxic and neurotoxic groups according to their functions [2]. The non-neurotoxic snake Kunitz/BPTI inhibitors include trypsin and chymotrypsin inhibitors. Another group acting as $\mathrm{K}^{+}$and $\mathrm{Ca}^{2+}$ channel blockers with little or no inhibitory activity is the neurotoxic snake Kunitz/BPTI. This group includes $\alpha$-dentrotoxin, toxin K, toxin I, calcicludine, and the small subunit of $\beta$-bungarotoxin from various snake sources [11,14]. Moreover, a trypsin inhibitor occuring in a complex containing a phospholipase A2 (PLA2) and a protease has also been reported [22]. The characteristically folded domain like that of a BPTI-like peptides is also found in several proteins, for example a human Alzheimer amyloid precursor protein [17], type VI collagen alpha3(VI) [27,41], tissue factor pathway inhibitor [1] and 
bikunin [38].

Although trypsin and chymotrypsin inhibitors are widely distributed in Russell's viper venom, to date only some inhibitors have been cloned. Peptides belonging to the Kunitz BPTI proteinase inhibitor family have very similar amino acid sequences, but display various functions. The present study describes the purification, properties, structure and cloning of chymotrypsin inhibitors from Burmese Daboia russelli siamensis venom. 


\section{Materials and methods}

\subsection{Materials}

Burmese Daboia russelli siamensis venom was purchased from Xinyuan Jiayu management department for snake venoms (Guangzhou, China), an agency of Rainbow Snake Farm (Yingtan City, Jiangxi Province, China). A Superdex ${ }^{\text {TM }}$ Peptide 10/300 GL column was purchased from Pharmacia (Uppsala, Sweden). POROS 50HS gel was bought from Perkin Elmer (Wellesley, MA, USA). A Jupiter $\mathrm{C}_{18}$ column was purchased from Phenomenex Inc. (Torrance, CA, USA). Benzoyl-D, L-4-arginine-p-nitroanilide (BAPNA) was obtained from Shanghai ShuiYuan Biotechnology Co. Ltd. (Shanghai, China). N-succinyl-Ala-Ala-Pro-Phe-p-nitroanilide was bought from Sigma (Missouri, USA). Bovine trypsin and chymotrypsin were bought from Shanghai Sheng Gong Biological Engineering and Technology Service Co. Ltd. (Shanghai, China) and Amesco (Carson, CA, USA), respectively. A Micro BCA ${ }^{\mathrm{TM}}$ Protein Assay Kit was obtained from Pierce Biotechnology Inc. (Rockford, Illinois, USA). A pGEM-T Easy vector and PCR Rapid Purification Kit were purchased from Promega (Madison, WI, USA) while a DNA Sequencing Kit (BigDye Terminator v3.1) was obtained from Applied Biosystems (Foster City, California, USA). All reagents used were of analytical grade.

\subsection{Isolation and Purification}

\subsubsection{Pretreatment of crude venom by heating}

One hundred milligrams of Burmese Daboia russelli siamensis venom were 
dissolved in $1.0 \mathrm{ml}$ of $0.4 / 99.6(\mathrm{v} / \mathrm{v})$ trifluoroacetic acid (TFA)/water. The venom solution was heated at $80{ }^{\circ} \mathrm{C}$ for $30 \mathrm{~min}$ in a water bath. The supernatant was prepared by centrifugation at $10,000 ! \mathrm{g}$ for $10 \mathrm{~min}$. The precipitate was washed twice using 0.4/99.6 (v/v) TFA/water, then the supernatant was pooled and concentrated using a Christ Alpha rotating vacuum concentration centrifuge (Martin Christ, Osterode am Harz, German).

\subsubsection{Superdex ${ }^{T M}$ Peptide 10/300 GL column chromatography}

The concentrated supernatant was applied to a Superdex ${ }^{\mathrm{TM}}$ Peptide 10/300 GL column $(1.5$ ! $30.0 \mathrm{~cm})$ equilibrated with $0.02 \mathrm{M}$ PBS buffer, $\mathrm{pH} 7.0$, containing $0.25 \mathrm{M}$ $\mathrm{NaCl}$ at a flow rate of $0.6 \mathrm{ml} / \mathrm{min}$. The chromatography was conducted using a Beckman Gold HPLC system (Beckman Instruments, Brea, CA, USA) at room temperature, the eluate monitored at $214 \mathrm{~nm}$ using a Beckman $166 \mathrm{UV}$ detector and fractions collected.2.2.3. POROS 50HS column chromatography

The fraction containing chymotrypsin inhibitor activity from gel filtration chromatography was collected and diluted four-fold (V/V) with $0.02 \mathrm{M}$ phosphate buffer, $\mathrm{pH}$ 7.0. High performance liquid chromatography (HPLC) of the diluted fractions was performed using a self-packed POROS 50HS column $(0.6 ! 15.0 \mathrm{~cm})$. The column was equilibrated with $0.02 \mathrm{M}$ phosphate buffer, $\mathrm{pH} 7.0$ at a flow rate of $1.0 \mathrm{ml} / \mathrm{min}$. The absorbed components were eluted with a linear gradient of $\mathrm{NaCl}$ from 0 to $0.35 \mathrm{M}$ in the equilibrium buffer for $140 \mathrm{~min}$ and 0.35 to $0.8 \mathrm{M} \mathrm{NaCl}$ for $100 \mathrm{~min}$. The chromatography was conducted using a CCPD 8000 HPLC system from Tosoh Co. (Tokyo, Japan) at room temperature, the eluate was monitored at $214 \mathrm{~nm}$ with a Beckman 166 UV detector and fractions were collected. 


\subsubsection{Purification of BBPTI-1 on reverse phase C-18 column}

The fractions with inhibitory activity against chymotrypsin from the POROS 50HS

column chromatography separation were loaded onto a Jupiter C-18 column (0.46! 15 $\mathrm{cm})$ equilibrated with $0.05 / 99.95(\mathrm{v} / \mathrm{v})$ trifluoroacetic acid (TFA)/water at a flow rate of $0.5 \mathrm{ml} / \mathrm{min}$. The absorbed components were eluted with a linear gradient from $0.05 / 79.95 / 20 \quad(\mathrm{v} / \mathrm{v} / \mathrm{v}) \quad \mathrm{TFA} /$ water/80\% acetonitrile to $0.05 / 65.45 / 34.5 \quad(\mathrm{v} / \mathrm{v} / \mathrm{v})$ TFA/water/80\% acetonitrile for $155 \mathrm{~min}$. The chymotrypsin inhibitors were concentrated by using a ZFQ 85A rotating vacuum concentrator (Shanghai Medical Machine Ltd, China) and a Christ RVC rotating vacuum evaporator (Martin Christ, Osterode am Harz, Germany) for further characterization. POROS 50HS column chromatography was then performed as described above.

\subsection{Characterization of BBPTI-1}

\subsubsection{Mass spectrometry}

MALDI-TOF MS of positive ions of trypsin inhibitors was carried out using a Voyager DE mass spectrometer (Voyager, Applied Biosystems, Warrington, UK) operated in linear mode. Alpha-cyano-4-hydroxycinnamic acid (Sigma, UK) $(10 \mathrm{mg} / \mathrm{ml})$ was prepared in a solution containing 0.1/49.9/50 TFA/water/acetonitrile. Calibration took place using a mixture of peptides of known mass (Laser Biolabs, Sophia-Antipolis, Cedex, France).

\subsubsection{Determination of peptide concentration}

A Micro $\mathrm{BCA}^{\mathrm{TM}}$ Protein Assay Kit (Pierce, USA) was used for determination of peptide concentrations using BSA (supplied with the kit) as the standard according to the manufacturer's protocol. 


\subsubsection{Amino acid sequence from automated Edman degradation}

Sequence determination of purified peptide was performed by Edman degradation using a protein sequencer (Applied Biosystems Model 476A, Perkin Elmer, MA, USA). The primary structure was obtained by comparing the elution position of standard PTH-AAs.

\subsubsection{Determination of chymotrypsin inhibitory activity and chymotrypsin inhibition constants $\left(K_{i}\right)$}

Chymotrypsin inhibitor activities were measured according to the Mikola and Mikkonen method [28] with modifications. Assays were performed by adding together $30 ! 1$ of $5.0 ! \mathrm{g} / \mathrm{ml}$ chymotrypsin solution (Amesco, USA), $10.0 ! 1$ of sample solution, $300.0 ! 1$ of $0.2 \mathrm{M}$ Tris-HCl buffer (pH 8.0) containing $0.02 \mathrm{M} \mathrm{CaCl}_{2}$ and $210.0 ! 1$ of distilled water. After the mixture was preincubated at $37{ }^{\circ} \mathrm{C}$ for $20 \mathrm{~min}$ in a water bath, $50 ! 1$ of preheated substrate $(1.5 \mathrm{mg} / \mathrm{ml}), \mathrm{N}$-succinyl-Ala-Ala-Pro-Phe- $p$-nitroanilide (Sigma, USA) were added to the assay solution and the mixture was further incubated at $37{ }^{\circ} \mathrm{C}$ for $5 \mathrm{~min}$. The enzymatic reaction was terminated by the addition of $60.0 ! 1$ of $30 \%$ acetic acid. Distilled water was used as the control. The mixture was centrifuged at $10,000 ! \mathrm{g}$ for $5 \mathrm{~min}$, and its absorbance read at $405 \mathrm{~nm}$.

For the determination of the chymotrypsin inhibitor $\mathrm{K}_{\mathrm{i}}$ value, an appropriate amount of chymotrypsin was incubated with two concentrations of substrate. Briefly, the mixture contained $50 ! 1$ of bovine chymotrypsin $(5.0 ! \mathrm{g} / \mathrm{ml})$, varying volumes of inhibitor also at a concentration of $5.0 ! \mathrm{g} / \mathrm{ml}, 300.0 ! 1$ of $0.2 \mathrm{M}$ Tris- $\mathrm{HCl}$ buffer ( $\mathrm{pH} 8.0$ ) containing 0.02 $\mathrm{M} \mathrm{CaCl}_{2}$ and an appropriate amount of distilled water to provide a total volume of 550.0 
!1. After the mixture was incubated at $37{ }^{\circ} \mathrm{C}$ for $20 \mathrm{~min}$ in a water bath, $50.0 ! 1$ of preheated substrate $(1.2 \mathrm{mg} / \mathrm{ml}$ or $0.6 \mathrm{mg} / \mathrm{ml})$ were added to the assay solution for a further incubation of $5 \mathrm{~min}$. The enzymatic reaction was terminated by the addition of $60.0 ! 1$ of $30 \%$ acetic acid. References were obtained by adding acetic acid before the substrate was added to mixture. After the mixture was centrifuged at $10,000 ! \mathrm{g}$ for 5 min, its absorbance was read at $405 \mathrm{~nm}$. A Dixon plot [10] of $1 / v$ versus I inhibitor concentration at two substrate concentrations was performed to estimate the inhibition constant and to determine if any activity was competitive or non-competitive. In such plots non-competitive activity is observed by lines converging on the $\mathrm{x}$ axis while for competitive activity lines converge above the $\mathrm{x}$ axis.

\subsubsection{Detection of trypsin inhibition activity}

Trypsin inhibitor activity was measured according to the Mikola and Mikkonen method [28] with modifications. Assays were performed by adding 50 ! 1 of trypsin solution $(5.0 ! \mathrm{g} / \mathrm{ml})$, varying concentrations of inhibitor, $300.0 ! 1$ of $0.2 \mathrm{M}$ Tris- $\mathrm{HCl}$ buffer ( $\mathrm{pH}$ 7.4) containing $0.02 \mathrm{M} \mathrm{CaCl}_{2}$, and distilled water to provide a final volume of 550 ! 1. After the mixture was preincubated at $37{ }^{\circ} \mathrm{C}$ for $20 \mathrm{~min}$ in a water bath, $50 ! 1$ of preheated substrate $(2.0 \mathrm{mM})$ (BAPNA) was added to the trypsin assay solution, and the mixture was further incubated at $37{ }^{\circ} \mathrm{C}$ for $5 \mathrm{~min}$. The enzymatic reaction was terminated by the addition of $60.0 ! 1$ of acetic acid. Distilled water was used as the control in place of protease inhibitor. After the mixture was centrifuged at $10,000 ! \mathrm{g}$ for $5 \mathrm{~min}$, its absorbance was read at $405 \mathrm{~nm}$. 


\subsection{Molecular cloning of cDNA encoding chymotrypsin inhibitors}

\subsubsection{Construction of cDNA libraries derived from lyophilized snake venom}

An mRNA isolation kit (Dynal Biotec., ASA, Oslo, Norway) was used to isolate mRNA. Briefly, $50.0 \mathrm{mg}$ of lyophilized Burmese Daboia russelli siamensis venom was dissolved in $1.0 \mathrm{ml}$ of lysis/binding buffer. Magnetized oligo-dT beads were used to isolate mRNA with polyadenylate according to manufacturer's protocol. The isolated mRNA was immediately used for a 3'-rapid amplification of cDNA ends (RACE) reaction to obtain the chymotrypsin inhibitor nucleic acid sequence based on a SMART-RACE kit (Clontech, Basingstoke, UK) method.

\subsubsection{Cloning of protease inhibitors}

A sense primer $\left(\mathrm{P}_{1}\right)$ sequence (5'-ATGTCTTCTGGAGGTCTTCTTCTCC-3') designed from the signal peptide was according to the $\mathrm{B}_{1}$ chain (BPTI peptide) cDNA of a PLA 2 [37]. PCR product was obtained by utilizing a nested universal primer (NUP) (an antisense primer) from the kit and a sense primer, $\mathrm{P}_{1}$. PCR was performed on a thermal cycler (ThermoHybaid, Franklin, MA, USA) using the following cycle: initial denaturing at $94^{\circ} \mathrm{C}$ for $3 \mathrm{~min}, 40$ cycles of PCR $\left(94{ }^{\circ} \mathrm{C}\right.$ for $30 \mathrm{~s}, 57^{\circ} \mathrm{C}$ for $30 \mathrm{~s}$, and $72{ }^{\circ} \mathrm{C}$ for $\left.3 \mathrm{~min}\right)$. The last cycle was $72^{\circ} \mathrm{C}$ for $10 \mathrm{~min}$. PCR product was analyzed by agarose gel electrophoresis. The 3-RACE reaction was purified by using the Wizard $^{\circledR} \mathrm{SV}$ Gel and PCR Clean-Up System (Promega, Madison, WI, USA). Purified PCR sample was transformed to pGEM-T Easy vector, and then cloned into JM 109 high efficiency competent cells (Promega, Madison, WI, USA) according to the protocol. Two primers 
flanking the inserts in pGEM-T Easy vectors were used to amplify the inserted gene and for DNA sequencing. The inserted genes containing approximately $500 \mathrm{bps}$ were selected for DNA sequencing by using a BigDye ${ }^{\circledR}$ Terminator v3.1 Cycle Sequencing Kit and an ABI 3100 automated DNA sequencer (Applied Biosystems, California, USA).

\subsection{Bioinformatics of nucleotide and amino acid sequences}

The AlignX programme of the Vector NTI Bioinformatics suite (Informax) was used for alignment of nucleotide sequences cloned from Burmese Daboia russelli siamensis venom and its similar analogs, and for alignment of amino acid sequences deduced from cloned cDNAs. Regions of local similarity between sequences were determined by BLAST searching (http://www.ebi.ac.uk/Tools/sss/ncbiblast). 


\section{Results}

\subsection{Purification of BBPTI-1}

When Burmese Daboia russelli siamensis venom was dissolved in $0.4 \%$ TFA water and heated at $80^{\circ} \mathrm{C}$ in a water bath for $30 \mathrm{~min}$, a significant amount of protein was precipitated and removed by centrifugation. Shown in Fig. 1a is the result of Superdex $^{\text {TM }}$ Peptide 10/300 GL column chromatography of the pretreated sample. Several peaks are shown in the chromatogram, of which one marked with an arrowhead was found to display chymotrypsin inhibition activity. The active fractions were pooled, and diluted four-fold with $0.02 \mathrm{M}$ phosphate buffer, $\mathrm{pH} 7.0$, then applied to a cation exchange POROS 50HS column resulting in the chromatogram shown in Fig. 1b. Nine peaks were obtained in all, of which peak 5 showed chymotrypsin inhibition activity. The fractions corresponding to peak 5 were further purified on a C-18 column to purify the active peptide, BBPTI-1 (Fig. 1c).

\subsection{Properties of BBPTI-1}

\subsubsection{Mass spectrometry}

Fig. 1d shows the MALDI-ToF mass spectrum of BBPTI-1, indicating that complete isolation of the chymotrypsin inhibitor peptide from crude venom had taken place. The mass spectral signal at $6872.81 \mathrm{~m} / \mathrm{z}$ represents the singly charged state of the peptide $\left([\mathrm{M}+\mathrm{H}]^{+}\right)$while $3438.10 \mathrm{~m} / \mathrm{z}$ represents the doubly charged state $\left([\mathrm{M}+2 \mathrm{H}]^{2+}\right)$. Deconvolution of these peaks provides masses for the peptide of $6874.20 \mathrm{Da}$ as derived from the doubly charged signal and $6871.81 \mathrm{Da}$ from the singly charged state. The 
discrepancy in mass is most likely due to the MALDI-ToF instrument operating to approximately $\pm 0.1 \%$ accuracy and for this reason the mass of $6874.20 \mathrm{Da}$ as derived from the doubly charged $3438.10 \mathrm{~m} / \mathrm{z}$ signal is preferred as it is subject to a lower potential error.

\subsubsection{Amino acid sequences of BBPTI-1}

Using automated Edman degradation, the partial N-terminal amino acid sequence of BBPTI-1 was found to be HDRPKFCYLPADPGECLAHMRSF.

\subsubsection{Determination of chymotrypsin inhibition constant}

The Dixon plot in Fig 2 shows that BBPTI-1 has chymotrypsin inhibition activity with a $\mathrm{K}_{\mathrm{i}}$ value of $4.77 \mathrm{nM}$. It was competitive in its activity with that of chymotrypsin as demonstrated in Fig. 2 by lines converging above the $\mathrm{x}$ axis (indicated by an arrowhead).

\subsubsection{Trypsin inhibition activity}

BBPTI-1 strongly inhibited chymotrypsin activity, but showed no detectable inhibitory activity against trypsin.

\subsection{Molecular cloning of cDNA encoding BBPTI-1 and BBPTI-5}

RT-PCR product with about 500 bps was obtained from the dry venom-derived libraries of Burmese Daboia russelli siamensis venom. Two cDNAs of BPTI peptides designated as BBPTI-1 and BBPTI-5, were consistently cloned from Burmese Daboia russelli siamensis venom by using one primer designed from the signal peptide, and another primer (NUP) from the kit for PCR analysis (Fig. 3A, Fig. 3B). The cDNA 
sequences of BBPTI-1 and BBPTI-5 show an open-reading frame consisted of 84 and 90 amino acid residues, respectively. Determination of the cDNA of purified BBPTI-1 was achieved by comparing the molecular mass and the N-terminal amino acid sequence of purified BBPTI-1 and the peptide sequence deduced from cDNA. In terms of molecular weight both are very similar. Assuming that cysteines are oxidized, the deduced cDNA sequence has an average molecular weight of $6873.79 \mathrm{Da}$ while the molecular weight of the mature peptide as determined by MALDI-ToF mass spectrometry using the doubly charged signal $(3438.10 \mathrm{~m} / \mathrm{z})$ shown in Fig. 1d is 6874.20 Da. These two values are in very close agreement and demonstrate that oxidation of cysteines to form disulfide bonds has indeed taken place.

\subsection{Comparison of nucleotide and amino acid sequences and homology research}

Alignment of nucleotide sequences of BBPTI-1, BBPTI-5, CBPTI-3 from Chinese Daoboia russellii russellii venom and IBPTI-III from Indian Daoboia russellii russellii venom (Fig. 4A) was performed by using the AlignX programme of the Vector NTI Bioinformatics suite (Life Technologies, UK). This revealed that these peptides have a high degree of similarity in nucleotide sequences in the translated signal peptide and 3' untranslated regions. An obvious gene deletion compared to BBPTI-1 cDNA was found in the BBPTI-5 nucleotide sequence open-reading frame, which resulted in changing the site of the termination codon and producing BBPTI-5 with 66 amino acid residues.

Alignment of BBPTI-1, BBPTI-5, CBPTI-3 and IBPTI-3 open-reading frame amino acid sequences (Fig. 4B) reveals they have a high degree of homology; in particular their 
signal peptide sequences are identical. Fig. 4A shows that BBPTI-1 contains 60 amino acids with 6 cysteine residues, whose positions in the amino acid sequences are conserved in the four peptides investigated. 


\section{Discussion}

In snake venoms, there are many serine protease inhibitors belonging to the BPTI-like superfamily. To date a number of BPTI-like superfamily serine protease inhibitors from Viperidae and Elapidae venoms have been purified or characterized $[3,4,12,13,15,16,18,19,25,26,29-31,32-34,35,36,39]$. In this paper, one chymotrypsin inhibitor, BBPTI-1, was purified to homogeneity from the venom of Burmese Daboia russelli siamensis by gel filtration, cation exchange and reversed phase chromatography. The purified BBPTI-1 is basic and heat stable, which has been elucidated by the procedures of preparing venom samples and subsequent purification. The precursor cDNAs of BBPTI-1 and unknown BBPTI-5 have been cloned from libraries derived from Burmese Daboia russelli siamensis venom according to a method developed in our laboratory [6].

The venom of Burmese Daboia russelli simensis was heated at $80^{\circ} \mathrm{C}$ for $30 \mathrm{~min}$, which resulted in the majority of protein being precipitated, so the purification procedures of BBPTI-1 became simpler. The molecular weight of BBPTI-1 is $6874 \mathrm{Da}$, (Fig. 1d) and is composed of 60 amino acid residues. BBPTI-1 showed competitive chymotrypsin inhibitory activity, but no detectable trypsin inhibitory activity. Generally, chymotrypsin inhibitors exhibit no inhibitory trypsin activity, as is the case with Oh11-1 from Ophiophagus hannah venom [3], CBPTI-3 from Chinese Daboia russellii siamensis [13] and NA-CI from Naja atra venom [39], but Ritonja reported a chymotrypsin inhibitor that inhibited trypsin and human kallikrein weakly [31]. The 
dissociation constant, $\mathrm{K}_{\mathrm{i}}$ value of BBPTI-1 is similar to that reported for a chymotrypsin inhibitor from Vipera ammodytes venom of $4.3 \mathrm{nM}$ [31], higher than CBPTI-3 from Chinese Daoia russullii siamensis venom, 2.55nM [13], but lower than the reported value for Oh11-1 from Ophiophagus hannah venom, $3.52 \mu \mathrm{M}$ [3] and NA-CI from Naja atra venom, $25 \mathrm{nM}[39]$.

The molecular weight of the mature BBPTI-1 peptide deduced from the cDNA sequence is $6873.79 \mathrm{Da}$ (http://www.peptidesynthetics.co.uk/tools/) assuming that cysteines are oxidized. This is in close agreement to the observed mass (6874.20Da) derived from MALDI-TOF mass spectrometry of the doubly charged signal (Fig. 1d). A comparison of cDNA of BBPTI-1, BBPTI-5, CBPTI-3 and IBPTI-III showed identical sequences in their signal peptide (Fig. 4B) and high similarity in the 3'-noncoding regions. A gene deletion compared to BBPTI-1 cDNA was found close to the 3'-terminal in BBPTI-5 cDNA, which resulted in a mature peptide with 66 amino acid residues. Following NCBI-BLAST (http://www.ebi.ac.uk/Tools/sss/ncbiblast/) mature peptide homology searching, 6 amino acid differences were noted for BBPTI-1 compared to CBPTI-3 and 7 amino acid differences compared to IBPTI-3, especially for the $\mathrm{P}_{1}$ position; in BBPTI-1 this is Leu instead of Met in CBPTI-3 and IBPTI-3 (Fig. 4B). BBPTI-1 showed 90\% similarity to CBPTI-3 (54/60) and 88\% to IBPTI-3 (53/60). Naja naja atra chymotrypsin inhibitor (NACI) genes [8] and several B chain genes of $\beta$-bungarotoxins have been reported by Cheng et al. [7], and they share virtually an identical structural organization containing 3 exons and 2 introns, and a high degree of 
sequence identity. This suggests that Kunitz/BPTI protease inhibitors and B chains may have originated from a common ancestor, as was also elucidated by comparing signal peptide amino acid sequences of snake Kunitz/BPTI proteins and obtain highly conserved sequences [40]. In this paper, highly conserved signal peptide sequences of Kunitz/BPTI proteins were also found (Fig. 4B). Moreover, by analyzing the protein sequences of the snake Kunitz/BPTI family, the progressive development of this family has been achieved by gene duplication followed by diversification $[7,40]$.

With regard to the competitive inhibition activity study, the $\mathrm{P}_{1}$ residue in the center of the binding loop is particularly important and its variants have been shown to greatly alter the specificity and potential activity of these peptides $[9,20]$. The $\mathrm{P}_{1}$ amino acid in many inhibitor families shows a high degree of variability [24]. Cardle and Dufton [2] analyzed the Kunitz BPTI proteinase inhibitor sequences for each subgroup containing different functions and revealed that amino acid side chains at interactive sites were conserved. A typical trypsin inhibitor has a positively charged Arg or Lys residue at $\mathrm{P}_{1}$, whereas a chymotrypsin inhibitor has a large hydophobic Phe, Leu, Met, Tyr, or Trp residue [23]. Two chymotrypsin inhibitors containing Asn at $\mathrm{P}_{1}$ were also found in Bungarus fasciatus venom [25] and Ophiophagus hannah venom [3]. In this study the $\mathrm{P}_{1}$ amino acid residue of BBPTI-1 and BBPTI-5 is leucine (Fig. 4B), providing further confirmation that these peptides are chymotrypsin inhibitors.

Snake venom Kunitz/BPTI inhibitors are considered to have influence on the processes of coagulation, fibrinolysis and inflammation [33] and protease inhibitors such 
as the polypeptides aprotinin and ulinastatin, have been used in pharmacological contexts.

In this paper the properties, structure and cloning of chymotrypsin inhibitors from Burmese Daboia russelli siamensis venom have been described.

\section{Acknowledgments}

Chunteng Guo was in receipt of a Vice Chancellor's Research Studentship at the University of Ulster. We thank the Fujian Government, People's Republic of China for financial support (project grant number 2000Z143) and other assistance. 


\section{References}

[1] Burgering MJ, Orbons LP, van der Doelen A, Mulders J, Theunissen HJ, Grootenhuis PD, et al. The second Kunitz domain of human tissue pathway inhibitor: cloning, structure determination and interaction with factor Xa. J Mol Biol 1997;269:395-407.

[2] Cardle L, Dufton MJ. Foci of amino acid residue conservation in the 3D structures of the Kunitz BPTI proteinase inhibitors: how do variants from snake venom differ? Protein Eng 1997;10:131-6.

[3] Chang L, Chung C, Huang HB, Lin S. Purification and characterization of a chymotrypsin inhibitor from the venom of Ophiophagus hannah (King Cobra). Biochem Biophys Res Commun 2001;283:862-7.

[4] Chang LS, Wang JJ, Cheng YC, Chou WM. Genetic organization of Bungarus multicinctus protease inhibitor-like proteins. Toxicon 2008;51:1490-5.

[5] Chen C, Hsu CH, Su NY, Lin YC, Chiou SH, Wu SH. Solution structure of a Kunitz-type chymotrypsin inhibitor isolated from the elapid snake Bungarus fasciatus. J Biol Chem 2001;276:45079-87.

[6] Chen T, Bjourson AJ, Orr DF, Kwok H, Rao P, Ivanyi C, et al. Unmasking venom gland transcriptomes in reptile venoms. Anal Biochem 2002;311:152-6.

[7] Cheng YC, Chen KC, Lin SK, Chan LS. Divergence of genes encoding B chains of beta-bungarotoxins. Toxicon 2006;47:322-9.

[8] Cheng YC, Yan FJ, Chang LS. Taiwan cobra chymotrypsin inhibitor: cloning, 
functional expression and gene organization. Biochim Biophys Acta 2005; 1747:213-20.

[9] Czapinska H, Helland R, Smalas AO, Otlewski J. Crystal structures of five bovine chymotrypsin complexes with P1 BPTI variants. J Mol Biol 2004;344:1005-20.

[10] Dixon M. The determination of enzyme inhibitor constants, Biochem J $1953 ; 55: 170-1$.

[11] Dufton MJ. Proteinase inhibitors and dendrotoxins. Sequence classification, structural prediction and structure/activity. Eur J Biochem 1985;153:647-54.

[12] Filippovich I, Sorokina N, Masci PP, de Jersey J, Whitaker AN, Winzor DJ, et al. A family of textilinin genes, two of which encode proteins with antihaemorrhagic properties. Br J Haematol 2002;119:376-84.

[13] Guo C, McClean S, Shaw C, Rao P, Ye M, Bjourson AJ. Trypsin and chymotrypsin inhibitor peptides from the venom of Chinese Daboia russellii siamensis. Toxicon $2012 ; 63: 154-164$.

[14] Harvey AL, Anderson AJ. Dendrotoxins: Snake Toxins That Block Potassium Channels and Facilitate Neurotransmitter Release. In: Harvey, AL, editor. Snake Toxins. Tarrytown, New York: Pergamon Press Inc; 1991, p. 131-64.

[15] He YY, Liu SB, Lee WH, Qian JQ, Zhang Y. Isolation, expression and characterization of a novel dual serine protease inhibitor, $\mathrm{OH}-\mathrm{TCI}$, from king cobra venom. Peptides 2008;29:1692-9.

[16] Hokama Y, Iwanaga S, Tatsuki T, Suzuki T. Snake venom proteinase inhibitors. III 
isolation of five polypeptide inhibitors from the venoms of Hemachatus haemachatus (Ringhal's cobra) and Naja nivea (cape cobra) and the complete amino acid sequences of two of them. J Biochem 1976;79:559-78.

[17] Hynes TR, Randal M, Kennedy LA, Eigenbrot C, Kossiakoff AA. X-ray crystal structure of the inhibitor domain of Alzheimer's amyloid beta-protein precursor. Biochemistry 1990;29:10018-22.

[18] Inagaki H, Kimoto H, Yamauchi Y, Toriba M, Kubo T. Functional characterisation of Kunitz-type protease inhibitor Pr-mulgins identified from New Guinean Pseudechis australis. Toxicon 2012;59:74-80.

[19] Joubert FJ, Strydom DJ. Snake venoms. The amino-acid sequence of trypsin inhibitor E of Dendroaspis polylepis polylepis (Black Mamba) venom. Eur J Biochem 1978;87:191-8.

[20] Krowarsch D, Dadlez M, Buczek O, Krokoszynska I, Smalas AO, Otlewski J. Interscaffolding additivity: binding of $\mathrm{P} 1$ variants of bovine pancreatic trypsin inhibitor to four serine proteases. J Mol Biol 1999;289:175-86.

[21] Kumar AV, Gowda TV. Novel non-enzymatic toxic peptide of Daboia russelii (Eastern region) venom renders commercial polyvalent antivenom ineffective. Toxicon 2006;47:398-408.

[22] Kumar JR, Basavarajappa BS, Arancio O, Aranha I, Gangadhara NS, Yajurvedi HN, et al. Isolation and characterization of "Reprotoxin", a novel protein complex from Daboia russelii snake venom. Biochimie 2008;90:1545-59. 
[23] Laskowski MJr, Kato I. Protein inhibitors of proteinases. Annu Rev Biochem 1980;49:593-626.

[24] Laskowski MJr, Apostol I, Ardelt W, Cook J, Giletto A, Kelly CA, et al. Amino acid sequences of ovomucoid third domain from 25 additional species of birds. $\mathrm{J}$ Protein Chem 1990;9:715-25.

[25] Liu CS, Wu TC, Lo TB. Complete amino acid sequences of two protease inhibitors in the venom of Bungarus fasciatus. Int J Peptide Protein Res 1983;21:209-15.

[26] Lu J, Yang HL, Yu HN, Gao WK, Lai R, Liu JZ, et al. A novel serine protease inhibitor from Bungarus fasciatus venom. Peptides 2008;29:369-74.

[27] Merigeau K, Arnoux B, Perahia D, Norris K, Ducruix A. 1.2 A refinement of the Kunitz-type domain from the alpha3 chain of human type VI collagen. Acta Crystallog D Biol Crystallogr 1998;54:306-12.

[28] Mikola M, Mikkonen A. Occurrence and stabilities of oat trypsin and chymotrypsin inhibitors. J Cereal Sci 1999;30:227-35.

[29] Ritonja A, Meloun B, Gubensek F. The primary structure of Vipera ammodytes venom chymotrypsin inhibitor. Biochim Biophys Acta 1983;746:138-45.

[30] Ritonja A, Meloun B, Gubensek F. The primary structure of Vipera ammodytes venom trypsin inhibitor I. Biochim Biophys Acta 1983;748:429-35.

[31] Ritonja A, Turk V, Gubensek F. Serine proteinase inhibitors from Viper ammodytes venom. Isolation and kinetic studies. Eur J Biochem 1983;133:427-32.

[32] Shafqat J, Beg OU, Yin SJ, Zaidi ZH, Jornvall H. Primary structure and functional 
properties of cobra (Naja naja naja) venom Kunitz-type trypsin inhibitor. Eur J Biochem 1990;194:337-41.

[33] Shafqat J, Zaidi ZH, Jornvall H. Purification and characterization of a chymotrypsin Kunitz inhibitor type of polypeptide from the venom of cobra (Naja naja naja). FEBS Lett 1990;275:6-8.

[34] Siddigi AR, Zaidi ZH, Jornvall H. Purification and characterization of a Kunitz-type trypsin inhibitor from Leaf-nosed viper venom. FEBS Lett 1991;294:141-3.

[35] Strydom DJ. Snake venom toxins. Purification and properties of low-molecular-weight polypeptides of Dendroaspis polylepis polylepis (black mamba) venom. Eur J Biochem 1976;69:169-76.

[36] Takahashi H, Iwanaga S, Kitagawa T, Hokama Y, Suzki T. Snake venom proteinase inhibitors. Chemical structure of inhibitor II isolated from the venom of Russell's viper (Viper russelli). J Biochem1974;76:721-33.

[37] Wu PF, Wu SN, Chang CC, Chang LS. Cloning and functional expression of B chains of b-bungarotoxins from Bungarus multicinctus (Taiwan banded krait). Biochem J 1998;334:87-92.

[38] Xu Y, Carr PD, Guss JM, Ollis DL. The crystal structure of bikunin from the inter- $\alpha$-inhibitor complex: a serine protease inhibitor with two Kunitz domains. J Mol Biol 1998;276:955-66.

[39] Zhou XD, Jin Y, Lu QM, Li DS, Zhu SW, Wang WY, et al. Purification, characterization and primary structure of a chymotrypsin inhibitor from Naja atra 
venom. Comp Biochem Physiol B Biochem Mol Biol 2004;137:219-24.

[40] Zupunski V, Kordis D, Gubensek F. Adaptive evolution in the snake venom Kunitz/BPTI protein family. FEBS Lett 2003;547:131-6.

[41] Zweckstetter M, Czisch M, Mayer U, Chu ML, Zinth W, Timpl R, et al. Structure and multiple conformations of the Kunitz-type domain from human type VI collagen alpha3(VI) chain in solution. Structure 1996;4:195-209. 

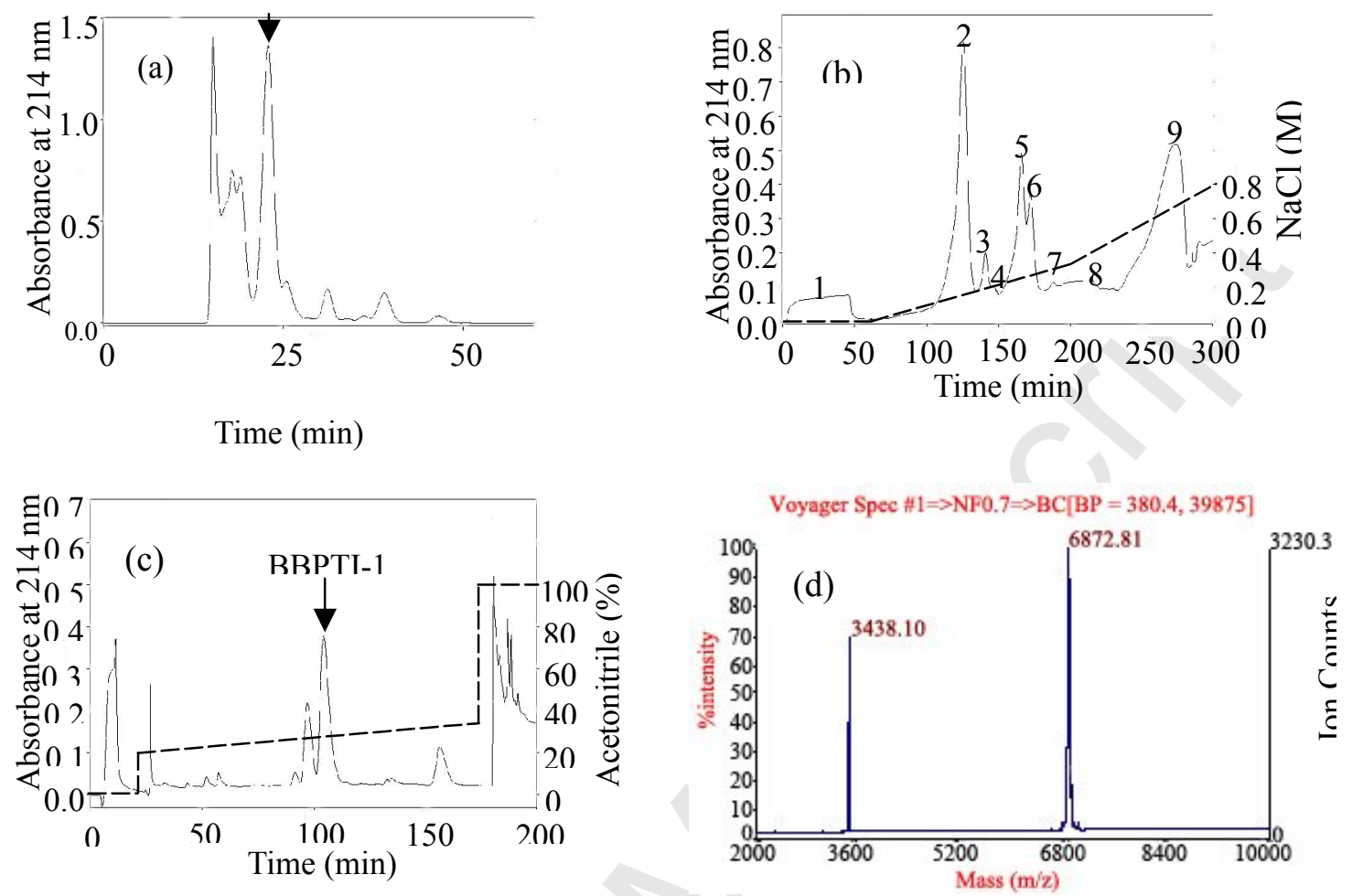

Fig. 1 


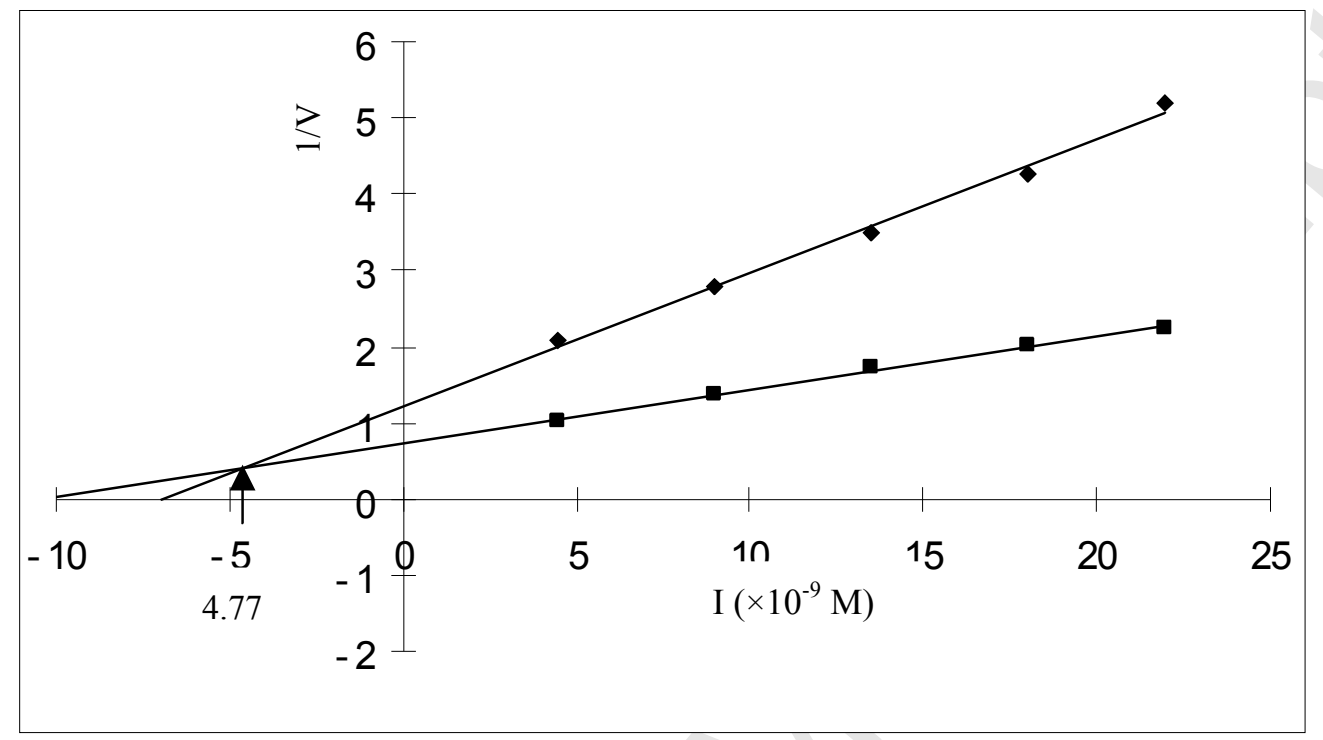

Fig. 2 
(A)

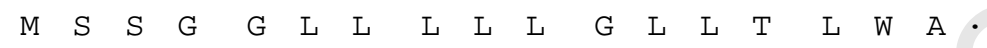

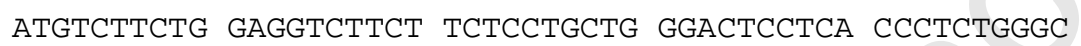
- $\begin{array}{llllllllllllllllll}\text { E } & \text { L } & \text { T } & \text { P } & \text { I } & S & G & \text { H } & \mathbf{D} & \mathbf{R} & \mathbf{P} & \mathbf{K} & \mathbf{F} & \mathbf{C} & \mathbf{Y} & \mathbf{L} & \mathbf{P} & \text {. }\end{array}$

51 AgAgCtGACC CCCATCTCCG GCCACGACCG TCCAAAgtTT TGTTATCtCC \begin{tabular}{llllllllllllllllll}
\hline & $A$ & $D$ & $P$ & $G$ & $E$ & $C$ & L & A & H & M & R & S & $\mathbf{F}$ & $\mathbf{Y}$ & $\mathbf{Y}$ & $\mathbf{D}$
\end{tabular}

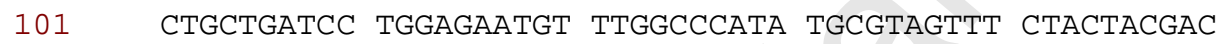
$\begin{array}{llllllllllllllllll}\mathbf{S} & \mathbf{E} & \mathbf{S} & \mathbf{K} & \mathbf{K} & \mathbf{C} & \mathbf{K} & \mathbf{E} & \mathbf{F} & \mathbf{I} & \mathbf{Y} & \mathbf{G} & \mathbf{G} & \mathbf{C} & \mathbf{H} & \mathbf{G} & \mathbf{N}\end{array}$

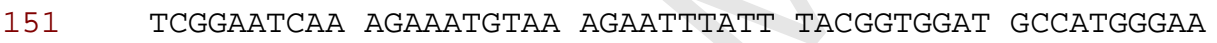
$\begin{array}{llllllllllllllllll}\cdot & \mathbf{A} & \mathbf{N} & \mathbf{K} & \mathbf{F} & \mathbf{P} & \mathbf{S} & \mathbf{R} & \mathbf{D} & \mathrm{K} & \mathbf{C} & \mathbf{R} & \mathbf{Q} & \mathbf{T} & \mathbf{C} & \mathbf{G} & \mathbf{G} & \mathrm{K}\end{array}$

201 TgCCAACAAg tTtCCGAgCA GgatiaAtg TCGCCAgACC TgtggtggtA

251 AgtAgCATCC GCAAAgGgGA GACCCACCTG AAtTGgGtCT AAtTCGCCAA

301 CtTCACtgAg AggCGtTCCt tCtgtCCtgg AttAttctgg AgAcCCtCCC

351 CCCAAACCCG CCCTGGCTTC ATCCCTTCTG TTCTGCAATA AAgCTTTGTT

401 CTCGCTGCAA AAAAAAAAAA AAAAAAAAAA

(B) $\begin{array}{llllllllllllllllllllllllllllllll}M & S & S & G & G & L & L & L & L & L & G & L & L & T & L & W & A & \cdot\end{array}$

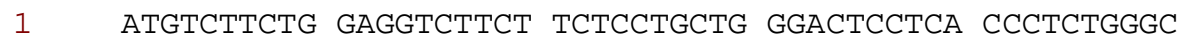

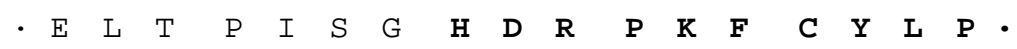

51 AgAgCtgACC CCCAtCtCCG GCCACGACCG tCCAAAgttT tgttAtCtCC $\begin{array}{lllllllllllllllll}\text { - } & \text { A } & \mathbf{D} & \mathbf{P} & \mathbf{G} & \mathbf{E} & \mathbf{C} & \mathrm{L} & \mathbf{A} & \mathbf{H} & \mathbf{M} & \mathbf{R} & \mathbf{S} & \mathbf{F} & \mathbf{Y} & \mathbf{Y} & \mathbf{D}\end{array}$ 


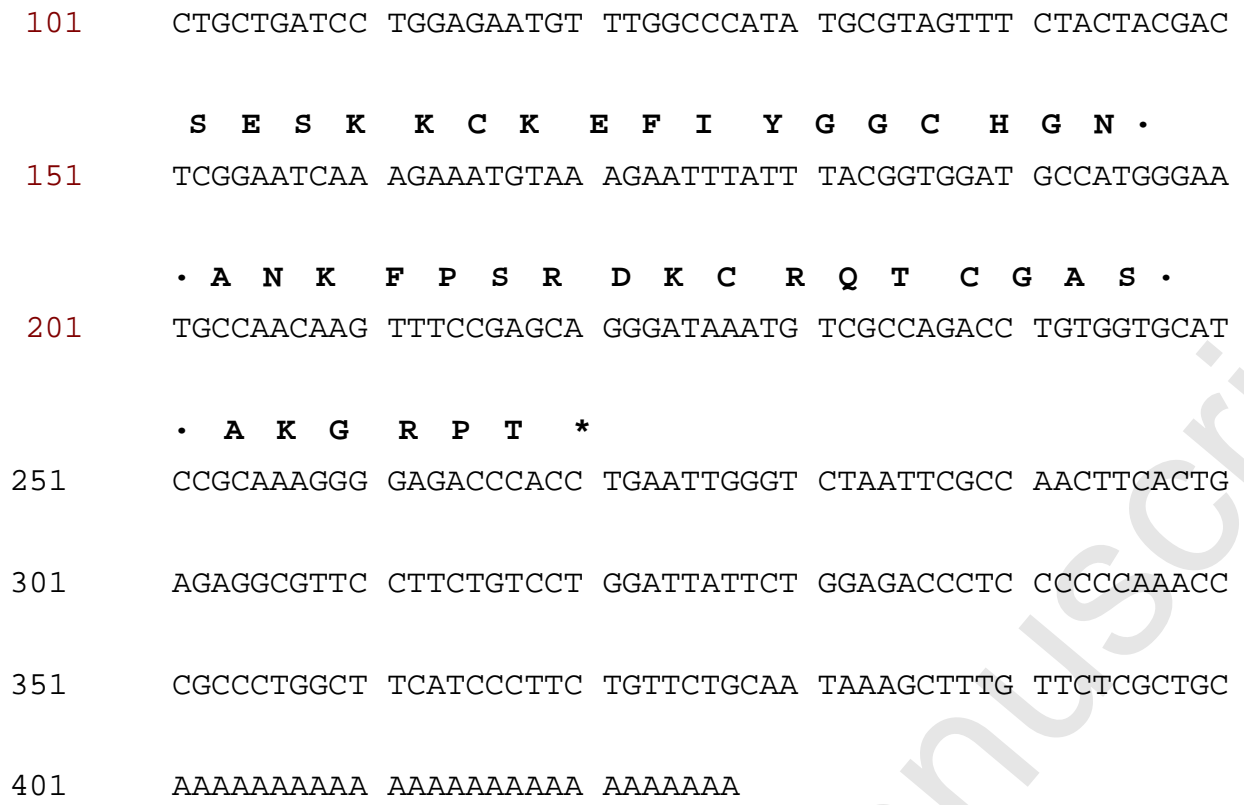

Fig. 3

(A) 1250
BBPTI-1
(1) ATGTCTTCTGGAGGTCTTCTTCTCCTGCTGGGACTCCTCACCCTCTGGGC
BBPTI -5
(1) ATGTCTTCTGGAGGTCTTCTTCTCCTGCTGGGACTCCTCACCCTCTGGGC
CBPTI -3
(1) ATGTCTTCTGGAGGTCTTCTTCTCCTGCTGGGACTCCTCACCCTCTGGGC
IBPTI-III
(1) ATGTCTTCTGGAGGTCTTCTTCTCCTGCTGGGACTCCTCACCCTCTGGGC
51
100
BBPTI-1 (51) AGAGCTGACCCCCATCTCCGGCCACGACCGTCCAAAGTTTTGTTATCTCC
BBPTI-5 (51) AGAGCTGACCCCCATCTCCGGCCACGACCGTCCAAAGTTTTGTTATCTCC
CBPTI-3 (51) AGAGCTGACCCCCATCTCCGGCCACGACCGTCCAAAGTTTTGTTATCTCC
IBPTI-III (51) AGAGCTGACCCCCATCTCCGGCCACGACCGTCCAAAGTTTTGTTATCTCC

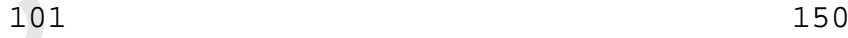

BBPTI-1 (101) CTGCTGATCCTGGAGAATGTTTGGCCCATATGCGTAGTTTCTACTACGAC

BBPTI-5 (101) CTGCTGATCCTGGAGAATGTTTGGCCCATATGCGTAGTTTCTACTACGAC

CBPTI-3 (101) CTGCTGATCCTGGAGAATGTATGGCCTATATCCGTAGTTTCTACTACGAC

IBPTI-III (101) CTGCTGATCCTGGAGAATGTATGGCCTATATCCGTAGTTTCCACTACGAC<smiles></smiles>

BBPTI-1 (151) TCGGAATCAAAGAAATGTAAAGAATTTATTTACGGTGGATGCCATGGGAA

BBPTI-5 (151) TCGGAATCAAAGAAATGTAAAGAATTTATTTACGGTGGATGCCATGGGAA

CBPTI-3 (151) TCGGAATCAAAGAAATGTAAAGAATTTATTTACGGTGGATGCCATGGGAA

IBPTI-III (151) TCGGAATCAAAGAAATGTAAAGAATTTATTTACGGTGGATGCCATGGGAA

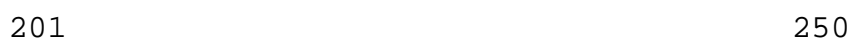

BBPTI-1 (201) TGCCAACAAGTTTCCGAGCAGGGATAAATGTCGCCAGACCTGTGGTGGTA 


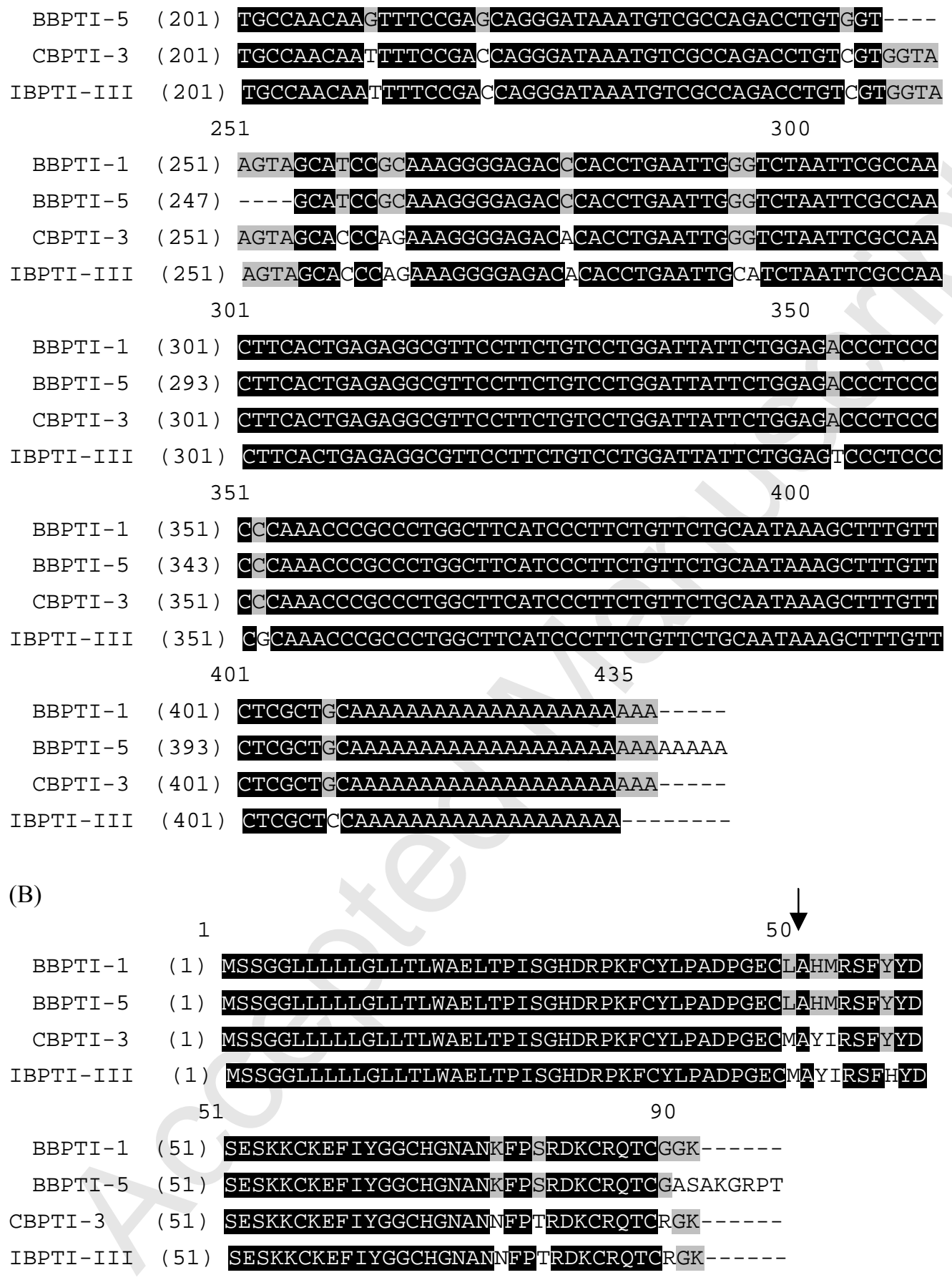

Fig. 4 
Fig. 1. Chromatographic and mass spectrometric profiles of BBPTI-1 purified from the venom of Burmese Daboia russellii siamensis. (a) Size exclusion HPLC profile of prepared Burmese Daboia Russelii siamensis venom. (b) Poros 50 HS cation exchange column purification of protease inhibitor fraction from size exclusion chromatography. (c) HPLC profile of components displaying chymotrypsin inhibition on a reversed phase C-18 column. (d) MALDI-TOF mass spectrum of purified BBPTI-1.

Fig. 2 Dixon plot showing inhibitory effects of BBPTI-1 on chymotrypsin activity on $\mathrm{N}$-succinyl-Ala-Ala-Pro-Phe- $\rho$-nitroanilide in the presence of substrate at concentrations of $0.08 \mathrm{mM}$ and $0.16 \mathrm{mM}$, respectively. Convergence of the lines above the $\mathrm{x}$ axis shows competitive activity (indicated by an arrowhead).

Fig. 3. cDNAs and deduced amino acid sequences of BBPTI-1 (A) and BBPTI-5 (B) precursors. Mature peptide sequence are denoted in bold. The sequence underlined was confirmed by automated Edman degradation. A stop code is indicated by an asterisk.

Fig. 4. Alignment of nucleotide sequences (A) and amino acid sequences (B) of BBPTI-1 (GenBank accession no. GenBank: $\underline{\mathbf{A M 4 1 1 3 6 8}}$ ), BBPTI-5 (GenBank accession no. GenBank: $\underline{\mathbf{A M 4 1 1 3 7 2}}$, CBPTI-3 (GenBank accession no. GenBank: $\underline{\mathbf{A M 4 1 1 3 6 3}}$ ) and IBPTI-III (GenBank accession no. GenBank: DQ365980). Identical bases and amino acids in all sequences are shaded in black while similar base and amino acid sequences are shaded in grey or in white. The arrow indicates the critical residue (site $\mathrm{P}_{1}$ ) of the antiprotease loop. Gaps are inserted for optimal alignment. 
Highlights

A novel chymotrypsin inhibitor, BBPTI-1, was found in Burmese Daboia russellii siamensis venom

BBPTI-1 showed strong chymotrypsin inhibition activity, but no trypsin inhibition activity BBPTI-1 was cloned along with another cDNA with an 8 nucleotide deletion 